\title{
Particle Size Distribution of Various Soil Materials Measured by Laser Diffraction-The Problem of Reproducibility
}

\author{
Cezary Polakowski *(D), Magdalena Ryżak (D), Agata Sochan, Michał Beczek (D), Rafał Mazur (D) \\ and Andrzej Bieganowski (D)
}

Institute of Agrophysics, Polish Academy of Sciences in Lublin, 20-290 Lublin, Poland; m.ryzak@ipan.lublin.pl (M.R.); a.sochan@ipan.lublin.pl (A.S.); m.beczek@ipan.lublin.pl (M.B.); r.mazur@ipan.lublin.pl (R.M.); a.bieganowski@ipan.lublin.pl (A.B.)

* Correspondence: c.polakowski@ipan.lublin.pl

check for updates

Citation: Polakowski, C.; Ryżak, M.; Sochan, A.; Beczek, M.; Mazur, R.; Bieganowski, A. Particle Size Distribution of Various Soil Materials Measured by Laser DiffractionThe Problem of Reproducibility. Minerals 2021, 11, 465. https:// doi.org/10.3390/min11050465

Academic Editors: Neda Vdović, Kristina Pikelj and Mavro Lučić

Received: 2 April 2021

Accepted: 26 April 2021

Published: 28 April 2021

Publisher's Note: MDPI stays neutral with regard to jurisdictional claims in published maps and institutional affiliations.

Copyright: (c) 2021 by the authors. Licensee MDPI, Basel, Switzerland. This article is an open access article distributed under the terms and conditions of the Creative Commons Attribution (CC BY) license (https:/ / creativecommons.org/licenses/by/ $4.0 /)$.
Abstract: Particle size distribution is an important soil parameter-therefore precise measurement of this characteristic is essential. The application of the widely used laser diffraction method for soil analysis continues to be a subject of debate. The precision of this method, proven on homogeneous samples, has been implicitly extended to soil analyses, but this has not been sufficiently well confirmed in the literature thus far. The aim of this study is to supplement the information available on the precision of the method in terms of reproducibility of soil measurement and whether the reproducibility of soil measurement is characterized by a normal distribution. To estimate the reproducibility of the laser diffraction method, thirteen various soil samples were characterized, and results were analysed statistically. The coefficient of variation acquired was lowest (3.44\%) for silt and highest for sand $(23.28 \%)$. Five of the thirteen tested samples were characterized by a normal distribution. The fraction content of eight samples was not characterized by normal distribution, but the extent of this phenomenon varied between soils. Although the laser diffraction method is repeatable, the measurement of soil particle size distribution can have limited reproducibility. The main cause seems to be small amounts of sand particles. The error can be amplified by the construction of the dispersion unit. Non-parametric statistical tests should be used by default for soil laser diffraction method analysis.

Keywords: particle size distribution; soil; normality tests

\section{Introduction}

The particle size distribution (PSD) is considered to be one of the most basic physical characteristics of the soil. This is because, on the one hand, it is quite a permanent and characteristic quantity, and, on the other hand, because it determines many other more difficult to measure quantities such as air-water relation, pore size distribution and water movement in the profile. Knowing the texture of the soil is important in research into the water and thermal properties [1-5], erosion susceptibility [6,7], gas exchange possibilities [8-10] and microbiological activity [11-14] of soils.

There are many methods of determining PSD. However, the most popular and the most widely used are sieve-sedimentation methods. After appropriate dispersion, the tested sample is sieved through a sieve with a mesh diameter of $63 \mu \mathrm{m}$. The residue on the sieve is weighed after drying. What passes through the sieve goes to a cylinder in which sedimentation takes place. During the sedimentation, a specific volume of the suspension is pipetted at appropriate times, at the assumed depth, and after drying, the weight of the collected sample is determined, giving information about the percentage of a given fraction in the examined sample [15].

Other methods of determining particle size distribution used in soil science laboratories are for example the organoleptic method, the Atterberg Limits Test, photosedimentation 
methods, x-ray method, electrical sensing zone method (the Coulter principle), photon correlation spectroscopy [16], static and dynamic image analysis [17,18], as well as automated scanning electron microscopy [19]. New methods have also been developed, for example, the dynamometer method [20] and integral suspension pressure method (Pario) [21]. Lastly, there is the ever more widely used laser diffraction method (LDM) [22-24]. LDM owes its growing popularity mainly to its short analysis time and the small sample needed to take a measurement.

The measurement of size distribution by laser diffraction is based on automatic computer analysis of the light coming into the detectors. The light from the laser is dispersed as it passes through a suspension containing the particles to be measured. The smaller the particles, the more the light is deflected at larger angles. Based on the signals from the scattered light that reaches the detectors, the software determines the size distribution in the sample being examined.

LDM, however widely used, still requires the works which allow the full characterization of its methodological characteristics. This method is considered precise [25] and a measure of a method's precision can be its repeatability. Repeatability can be defined as the degree of compliance of subsequent measurements of the same measured quantity, carried out under the same measurement conditions [26]. The question arises: is it possible to ensure "the same measurement conditions" in soil PSD measurements?

Soil is a heterogenic material. This means that PSD may be different in different places of the same field. Therefore, it is practically impossible to sample two identical portions of the soil. If so-it is not valid to use the term "repeatability" in PSD measurements because its definition is not fulfilled-the measurement conditions are not the same. A much better term that should be used in such situations is reproducibility [26]. Therefore, this term will be used in this work.

Reproducibility may be expressed as any statistical measure describing the scattering of the results (such as range, standard deviation or coefficient of variation). In the case of soil PSD, it is important to use measurements made after the addition of a new portion of soil into the measuring system of the laser diffractometer because only such replications can take into account the natural heterogeneity of soils.

Because our review of the literature showed that up until now there has been only one publication about the reproducibility of PSD measurements using LDM [27], the aim of this work was to complement this information and show the relationship between reproducibility in relation to the content of various fractions. An additional aim was to answer the question of whether results could be characterized by normal distribution. The answer to this question seems to be useful for many soil science scientists because it would justify the use of parametric statistical tests-which are commonly used without any check as to whether the results distribution is normal or not [28].

\section{Materials and Methods}

2.1. Soils

Thirteen soil samples were collected from different parts of Poland, from the 13 soil profiles (description in Table 1). The criterion of soil selection was to obtain a wide range of soil textures. Samples were air-dried, sieved using a 2-mm sieve and stored for further use. Because common opinion-summarized in the work of Bieganowski et al. [29] has it that LDM underestimates the finest soil fractions, we decided to use the hydrometer method according to ISO11277:2020 [15] for texture classification and these results are shown in Figure 1. Briefly-material passing through the $2 \mathrm{~mm}$ aperture was subjected to removal of organic matter and salts, dispersed chemically and wet sieved. Then, material passing through the $0.063 \mathrm{~mm}$ aperture was transferred to cylinder, filled with water and after reaching a stable temperature, shaken for $2 \mathrm{~min}$. PSD was calculated from subsequent readings of dispersion density at specified intervals. The carbon contents in the investigated soils-measured with a Shimadzu TOC VCPH coupled with a Shimadzu SSM5000 (Shimadzu, Kyoto, Japan)—are presented in Table 1. 
Table 1. Basic properties of investigated soils. The particle size distribution (PSD) presented in this table was measured using the hydrometer method. IC—inorganic carbon; TOC—-total organic carbon.

\begin{tabular}{|c|c|c|c|c|c|c|c|c|}
\hline \multirow[b]{2}{*}{ Soil No. } & \multirow[b]{2}{*}{ GPS Coordinates } & \multirow[b]{2}{*}{$\begin{array}{l}\text { Soil Horizon } \\
(\mathrm{cm})\end{array}$} & \multirow[b]{2}{*}{$\begin{array}{l}\text { Soil Unit According } \\
\text { to WRB * }\end{array}$} & \multicolumn{3}{|c|}{ PSD (\%) } & \multirow[b]{2}{*}{$\begin{array}{l}\text { IC } \\
(\%)\end{array}$} & \multirow[b]{2}{*}{$\begin{array}{r}\text { TOC } \\
(\%)\end{array}$} \\
\hline & & & & $\begin{array}{c}\text { Sand } \\
(0.05-2.00 \mathrm{~mm})\end{array}$ & $\begin{array}{c}\text { Silt } \\
(0.002-0.05 \mathrm{~mm})\end{array}$ & $\begin{array}{c}\text { Clay } \\
(<0.002 \mathrm{~mm})\end{array}$ & & \\
\hline 1 & $54^{\circ} 6^{\prime} \mathrm{N} 15^{\circ} 29^{\prime} \mathrm{E}$ & A $15-20$ & Brunic Arenosol & 91 & 8 & 1 & 0.00 & 1.72 \\
\hline 2 & $54^{\circ} 13^{\prime} \mathrm{N} 21^{\circ} 13^{\prime} \mathrm{E}$ & A $15-20$ & Haplic Phaeozem & 44 & 40 & 16 & 0.00 & 3.43 \\
\hline 3 & $50^{\circ} 44^{\prime} \mathrm{N} 23^{\circ} 49^{\prime} \mathrm{E}$ & A $0-25$ & Haplic Chernozem & 24 & 70 & 6 & 0.04 & 3.11 \\
\hline 4 & $51^{\circ} 04^{\prime} \mathrm{N} 21^{\circ} 49^{\prime} \mathrm{E}$ & А $0-25$ & Rendzic Leptosol & 62 & 22 & 16 & 0.04 & 1.92 \\
\hline 5 & $51^{\circ} 01^{\prime} \mathrm{N} 18^{\circ} 03^{\prime} \mathrm{E}$ & A $0-25$ & Haplic Luvisol & 71 & 27 & 2 & 0.00 & 1.14 \\
\hline 6 & $50^{\circ} 10^{\prime} \mathrm{N} 17^{\circ} 50^{\prime} \mathrm{E}$ & А $0-35$ & Mollic Gleysol & 9 & 83 & 8 & 0.00 & 1.70 \\
\hline 7 & $52^{\circ} 55^{\prime} \mathrm{N} 14^{\circ} 16^{\prime} \mathrm{E}$ & A $20-30$ & Cambic Phaeozem & 51 & 18 & 31 & 0.00 & 0.82 \\
\hline 8 & $54^{\circ} 16^{\prime} \mathrm{N} 20^{\circ} 55^{\prime} \mathrm{E}$ & C $100-105$ & Haplic Vertisol & 7 & 20 & 73 & 1.16 & 0.54 \\
\hline 9 & $54^{\circ} 18^{\prime} \mathrm{N} 20^{\circ} 20^{\prime} \mathrm{E}$ & A $15-20$ & Haplic Vertisol & 16 & 49 & 35 & 0.00 & 3.19 \\
\hline 10 & $54^{\circ} 19^{\prime} \mathrm{N} 20^{\circ} 21^{\prime} \mathrm{E}$ & C $125-130$ & Haplic Vertisol & 5 & 46 & 49 & 1.89 & 0.92 \\
\hline 11 & $52^{\circ} 54^{\prime} \mathrm{N} 18^{\circ} 1^{\prime} \mathrm{E}$ & В $40-50$ & Vertic Cambisol & 16 & 34 & 50 & 0.00 & 0.55 \\
\hline 12 & $52^{\circ} 50^{\prime} \mathrm{N} 20^{\circ} 51^{\prime} \mathrm{E}$ & А $0-20$ & Pellic Vertisol & 37 & 31 & 32 & 0.00 & 1.81 \\
\hline 13 & $50^{\circ} 30^{\prime} \mathrm{N} 19^{\circ} 52^{\prime} \mathrm{E}$ & В $30-40$ & Eutric Cambisol & 40 & 16 & 44 & 1.04 & 0.70 \\
\hline
\end{tabular}

* World Reference Base for Soil Resources 2014: International Soil Classification System for Naming Soils and Creating Legends for Soil Maps. Update 2015 [30].

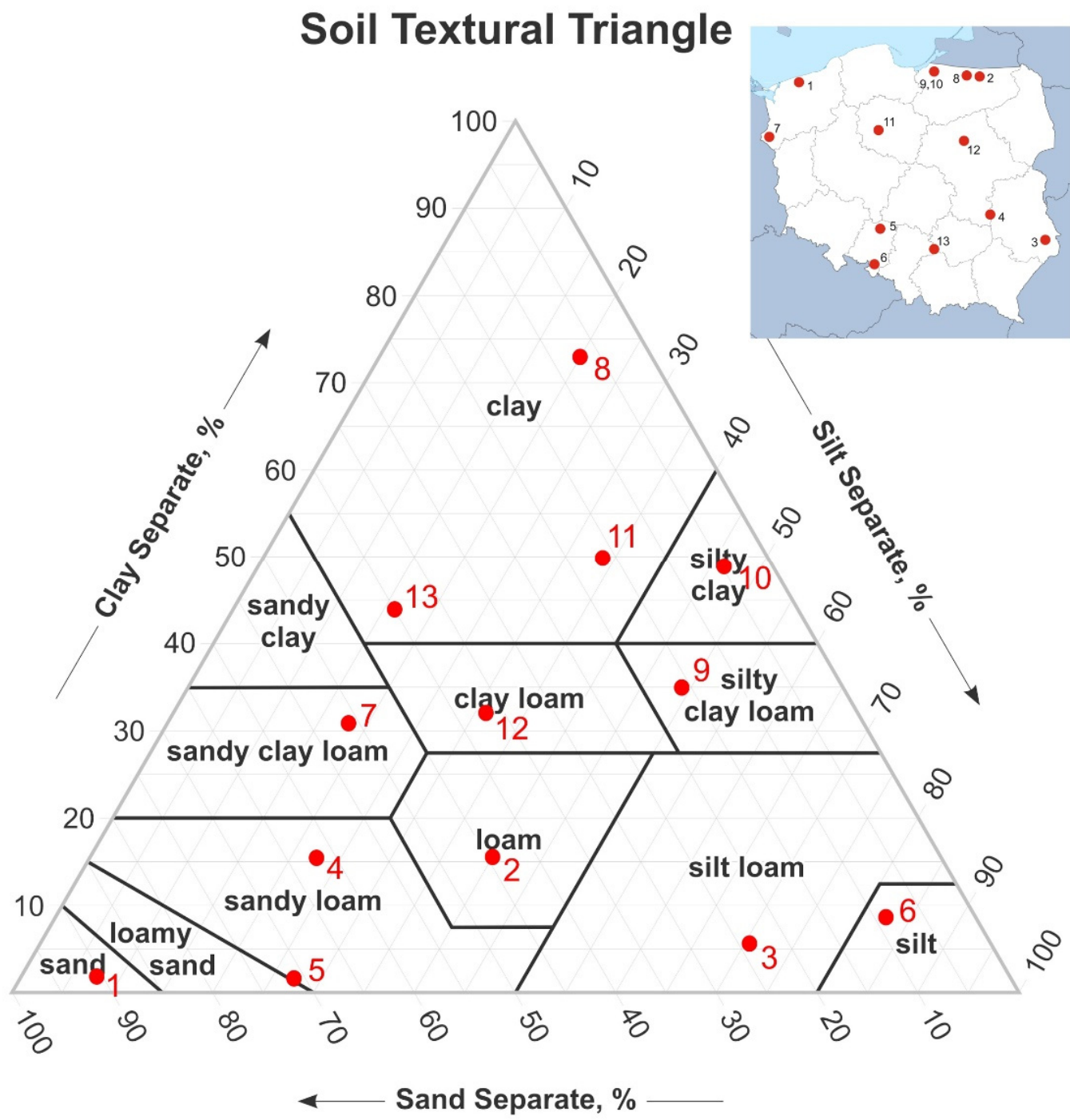

Figure 1. Sampling sites map and graphical representation of which particular texture groups soil samples belong to. PSD, which was the basis for this classification, was measured using the hydrometer method. 


\subsection{LDM Measurements}

To estimate the reproducibility of LDM, a laser diffractometer Mastersizer 2000 (Malvern Instruments, Malvern, UK) with Hydro G dispersion unit was used. Measurements were performed in degassed, distilled water dispersion and air trapped in the system was removed before measurement by switching off the unit briefly. The length of a single measurement was $60 \mathrm{~s}$ (30 s for red light and $30 \mathrm{~s}$ for blue light), the pump speed was $1750 \mathrm{rpm}$ and the stirrer speed $700 \mathrm{rpm}$. To calculate particle size distribution the Mie theory was used with refractive index $=1.52$ and absorption index $=0.1$ [31] During the measurements, the obscuration value was between 10-20\% (Mastersizer 2000 user manual). Dry soil samples were added to the measuring system and were subjected to $4 \mathrm{~min}$ of ultrasound at maximum power $(35 \mathrm{~W})$. All measurements were carried out in physical 30 repetitions (i.e., 30 soil dosings into the measurement system) and each physical replication was the result of 3 device replications (i.e., after each sample of soil was dosed into the measuring system, the measurement consisted of 3 replications, for which the average value was treated as a single result). LDM precision (total uncertainty) at 2 standard deviations is estimated at $5 \%$ [32].

\subsection{Statistical Analysis}

Coefficient of variation (CV) was used as the measure of reproducibility. Because CV is defined as the ratio of the standard deviation to the average (expressed as a percentage), then the lower the CV value, the higher the reproducibility. The Shapiro-Wilk (SW) test was used to verify the normality of distributions. All statistical calculations were carried out using Statistica software (ver. 13.1, StatSoft Polska, Cracow, Poland).

\section{Results}

\subsection{Reproducibility of LDM Results}

The PSDs measured using LDM and the reproducibility, expressed as the coefficient of variations (CV), obtained for the investigated soils are presented in Table 2. Sample PSD obtained by LDM is presented on Figure 2.

Table 2. Average fraction content with coefficients of variation (CV) from 30 repetitions for each soil.

\begin{tabular}{ccccccc}
\hline \multirow{2}{*}{ Soil No. } & \multicolumn{2}{c}{ Sand (0.05-2.00 mm) } & \multicolumn{2}{c}{ Silt (0.002-0.05 mm) } & \multicolumn{2}{c}{ Clay (<0.002 $\mathbf{~ m m})$} \\
& Content (\%) & CV (\%) & Content (\%) & CV (\%) & Content (\%) & CV (\%) \\
\hline 1 & 89.02 & 1.16 & 10.19 & 9.13 & 0.79 & 13.79 \\
2 & 25.63 & 9.81 & 66.19 & 3.17 & 8.18 & 6.72 \\
3 & 26.68 & 7.01 & 69.33 & 2.42 & 3.99 & 5.53 \\
4 & 57.25 & 2.25 & 40.18 & 3.02 & 2.58 & 4.44 \\
5 & 70.11 & 2.16 & 27.69 & 5.06 & 2.20 & 5.58 \\
6 & 19.19 & 6.64 & 74.5 & 1.56 & 6.31 & 3.66 \\
7 & 44.21 & 3.10 & 49.77 & 2.29 & 6.02 & 5.33 \\
8 & 1.32 & 106.50 & 79.80 & 2.09 & 18.88 & 7.43 \\
9 & 20.55 & 11.83 & 69.39 & 2.84 & 10.06 & 5.72 \\
10 & 0.76 & 98.44 & 84.9 & 0.71 & 14.34 & 6.24 \\
11 & 7.44 & 34.92 & 79.78 & 3.26 & 12.78 & 5.67 \\
12 & 36.35 & 8.67 & 56.70 & 4.60 & 6.95 & 11.75 \\
13 & 31.69 & 10.22 & 62.18 & 4.66 & 6.14 & 6.64 \\
Average & - & 23.28 & - & 3.44 & - & 6.81 \\
\hline
\end{tabular}



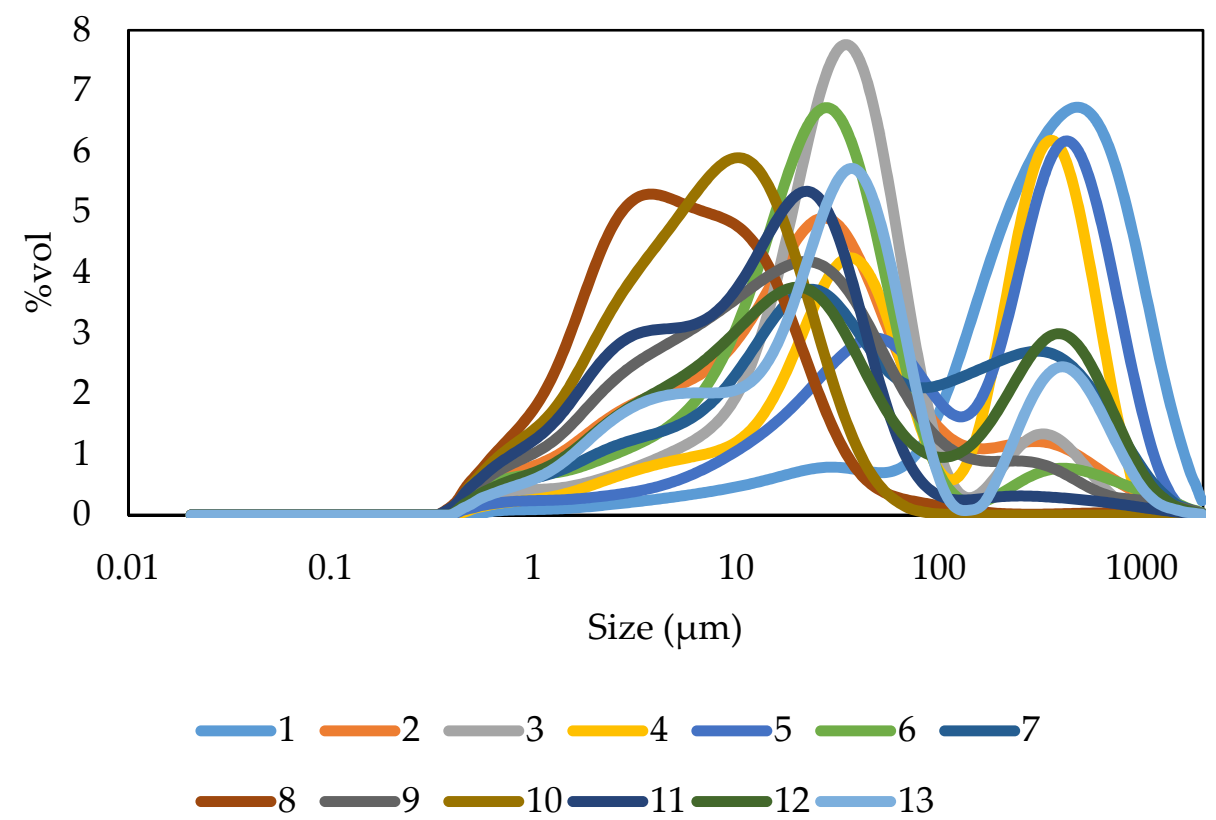

Figure 2. Samples PSD obtained by LDM.

The average CV value (Table 2) for the silt fraction was the lowest and equal to $3.44 \%$. The lowest CV for this fraction was $0.71 \%$ while the highest was $9.13 \%$. The average CV value for the clay fraction was higher and equal to $6.81 \%$. The lowest CV for the clay fraction was $3.66 \%$ while the highest was $13.79 \%$. The highest average CV value was obtained for the sand fraction-23.28\%. It should be noted that although the averaged CV value itself could be considered acceptable, the extremely large spread of obtained values for the sand fraction for individual soils, which ranged from $1.16 \%$ to $106.5 \%$, is alarming.

The relationships between the content of individual fractions and the CV value are presented in Figure 3.

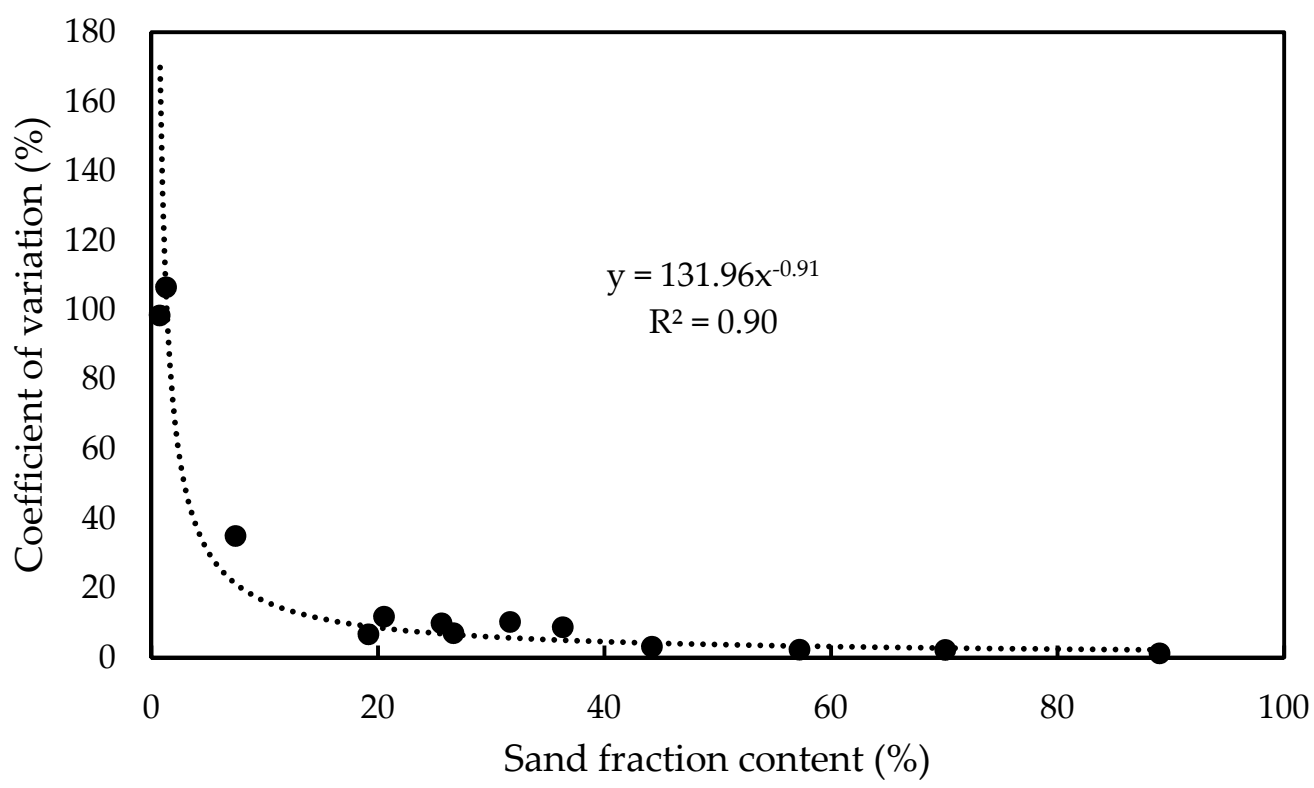

(a)

Figure 3. Cont. 


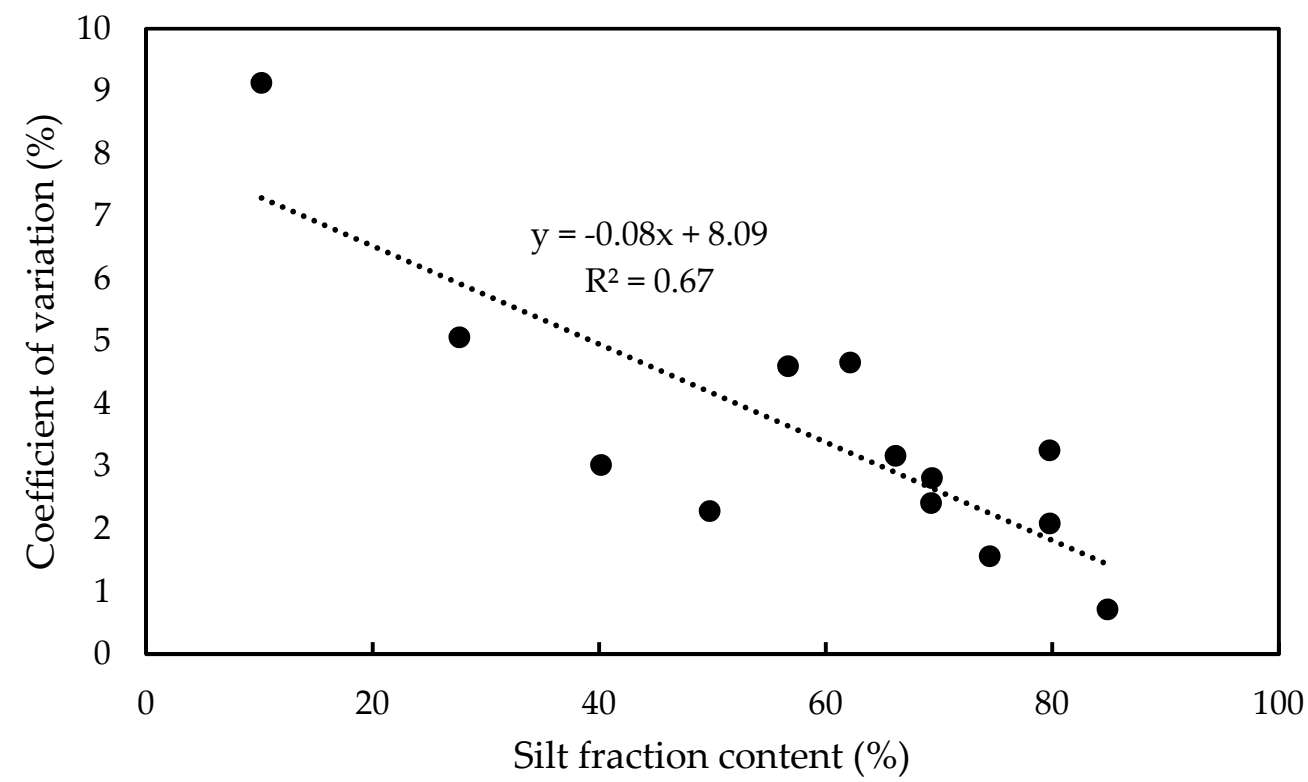

(b)

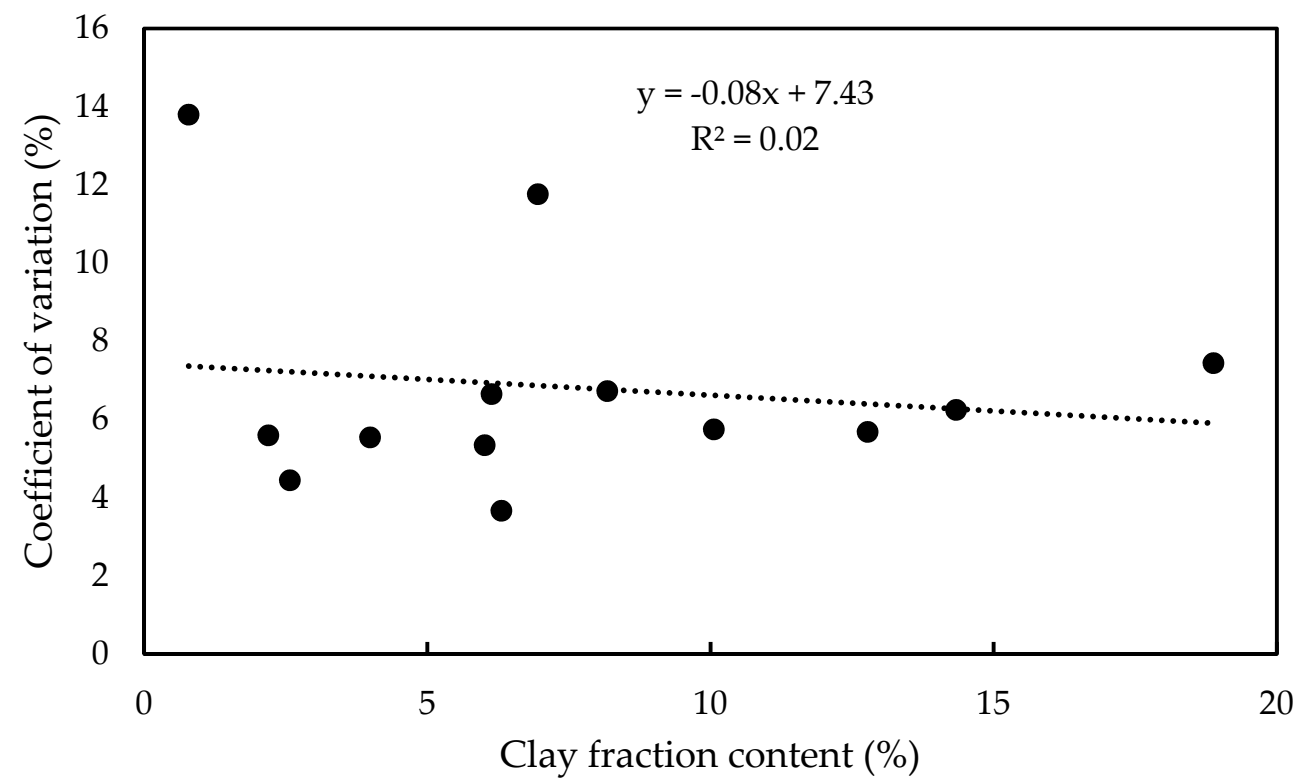

(c)

Figure 3. Relationship between coefficient of variation and individual fraction contents: (a)—sand; (b) —silt; (c)—clay.

The relationship between sand fraction content and CV was well described by the power function. The highest values of $\mathrm{CV}$ were obtained for samples containing a very small amount of sand particles, i.e., about $1 \%$. The higher the sand fraction content, the lower the scattering of the results. Interpolation by straight line was a better approximation for describing the analogous relationship for the silt fraction. The trend was the same (i.e., the larger the amount of fraction content, the smaller the scattering of results) but the decrease was not so rapid. There was no visible trend in the case of clay fraction content. Although for the smallest clay fraction content, the CV value was the largest (about 14\%), for the other clay contents, the scattering of $\mathrm{CV}$ values was rather random. 


\subsection{Verification of the Normality of Distributions}

The results of the verification of normality of distribution were obtained using the SW test are presented in Table 3.

Table 3. Results of the Shapiro-Wilk normality tests. Highlighted results (grey color) indicate cases for which there was no normal distribution $(n=30 ; p \leq 0.05)$.

\begin{tabular}{cccc}
\hline Soil No. & Sand & Silt & Clay \\
\hline 1 & 0.652 & 0.434 & 0.938 \\
2 & 0.137 & 0.085 & 0.823 \\
3 & 0.429 & 0.361 & 0.840 \\
4 & 0.052 & 0.048 & 0.149 \\
5 & 0.799 & 0.886 & 0.027 \\
6 & 0.654 & 0.477 & 0.074 \\
7 & 0.372 & 0.386 & 0.578 \\
8 & 0.000 & 0.443 & 0.007 \\
9 & 0.017 & 0.022 & 0.788 \\
10 & 0.000 & 0.587 & 0.052 \\
11 & 0.019 & 0.020 & 0.148 \\
13 & 0.002 & 0.001 & 0.217 \\
\hline
\end{tabular}

Five of the thirteen tested samples were characterized by normal distribution, taking into account the content of all texture fractions. The lack of distribution normality for one fraction occurred in 3 cases and in 5 cases for two fractions. There was not a single case of lack of normality for all three texture fractions.

\section{Discussion}

\subsection{Comparison of the PSD Obtained by Hydrometed and Laser Diffraction Methods}

The first observations which should be noted, and which are very evident in some soils, are the differences between clay content measured using the sieve-sedimentation method (Table 1) and LDM (Table 2). Because this phenomenon is very well known and widely described $[23,24,33-37]$ we would like to summarise only the main reasons for the differences reported in the above-cited papers. These reasons are: particle shape deviation from a spherical shape; incorrectly estimated optical indices; insufficient dispersion; construction of the sample mixing vessel; too low or too high a number of particles in one fraction.

\subsection{Reproducibility of LDM Results}

Goossens [27] previously found that laser diffraction in soil measurements, in comparison to many optical and sedimentation methods, is very repeatable and its precision is generally high. A similar opinion was expressed by Roberson and Weltje [38]. In the context of the data presented in Table 2 and Figure 3, such a statement should be rather worded as follows: although LDM is itself a repeatable method, the reproducibility of soil measurements depends on the soil.

Analyzing the data presented in Figure 3, it can be stated that for the finest (clay) fraction there was no visible dependence between reproducibility and the fraction content and CV was generally below $10 \%$ (in two cases CV $>10 \%$ ). The case was different for coarser fractions (silt and sand). The higher the content of each of these fractions, the more reproducible the measurement was. The greatest problem with reproducibility of results was observed for samples with low sand fraction content, which seems to contradict the observation reported by Goosens [27]. However, the Goosens study was carried out for very limited texture classes of soils (mainly silt and silt loam). In our study, most of the samples where $\mathrm{CV}$ was high were either sandy or clayey. In the case of samples which size distribution departing from normality, the soils from texture classes which represent high 
clay content were generally overrepresented. In these terms, our study is consistent with Goosens' data [27].

An explanation for such a relationship may be considered the work of Polakowski et al. [39]. The authors stated, with the example of glass beads which had the size of sand fractions, that when a small number of such coarse particles had been in the measuring system, these particles were very often not "visible" to the device because they had been passing through the measuring cell statistically rarely. Such random appearance of sand size particles in the measuring cell resulted in a large scattering of the results. The authors of the cited work found that there is a "boundary" value of the sand size particle content, above which the results become reproducible, which was similar to the result presented in Figure 3a. It should be noted that both experiments (i.e., in this work and in the paper by Polakowski et al. [39]) were carried out using the same laser diffractometer. It can be expected that the use of a different device would have resulted in another value for the sand boundary content because the result of this fraction is strongly dependent on the geometry and where the inlet of the measured mixture into the measuring cell is placed [40].

All the above considerations concerned sand fractions. However, this may also be the same mechanism for the relatively low reproducibility for silt when the content of this fraction is small (Figure 3b).

The problem of low reproducibility didn't arise for clay fraction (Figure 3c). This may be explained based on the fact that clay particles are very small. This means that even when the content of this fraction is small, the number of the clay size particles is large. If so- there were no problems with their uptake into the measuring system.

\subsection{Verification of the Normality of Distributions}

In practice, a verification of the normality of data distribution is carried out to assess which statistical tests can be used to determine the significance of differences between results or to examine their interaction with each other. If the distribution of obtained values is normal, then parametric tests can be used. Parametric tests have been used by many authors [34,35,41-43], but often the publications omitted information on the normality of distributions-this issue is not only true for this specific topic, over $90 \%$ of studies analyzed by Tavares et al. [28] did not have any normality tests. For data sets that are not normal distributions, non-parametric tests should be used, which are considered "weaker" tests.

It is difficult to clearly state what the reason is for the lack of normality of decomposition in the tested soils. In the case of soils No. 8, 10 and 13, whose distributions were not normal, a higher carbonate content was observed in relation to other samples, which could be the cause of this phenomenon. In the remaining samples, it was not possible to explain the reason for the lack of normal distributions, but this was not the purpose of this study. On the basis of the conducted research, we wanted to emphasize that in the case of analyses of soil samples, the normality of distributions should always be checked.

Based on the acquired results, it can generally be said that non-parametric tests should be used for LDM results analysis unless the normality check is positive and parametric tests can be used. Furthermore, samples with low content of one fraction should be analyzed more carefully as long as previously found sample homogeneity problems [39] are not resolved.

\section{Conclusions}

Although the laser diffraction method itself is repeatable and is characterized by a high resolution, the measurement of soil particle size distribution can have limited reproducibility. The main cause of low reproducibility seems to be the situation when the soil sample has a small amount of sand particles. The consequences of this are the rare appearance of such particles in the measuring cell and them not being taken into account in particle size distribution calculations. This error can be amplified by the construction of the dispersion unit. When the inlet to the measuring system is high above the bottom of the vessel, the stirring in the dispersion unit is not efficient enough to move heavy particles 
of sand into this inlet. When the inlet is low, heavy particles enter the measuring cell more often than it would appear from their fraction ratio. In both situations, the measurement is not representative, and a high scattering of the results occurs. For the soils investigated in this work, the scattering of the coefficient of variation was from $3.44 \%$ for the silt fraction to $23.28 \%$ for the sand fraction (on the basis of 30 replications).

This scattering of results can be the cause for the lack of normality of a given fraction content in particle size distribution. About half the results we obtained were characterized by a normal distribution in our investigations. The conclusion is therefore: the non-parametric statistical tests should be used for any statistical comparison unless the normality of distribution of each fraction content is confirmed for a given soil.

Author Contributions: Conceptualisation, C.P. and A.B.; validation, C.P., R.M. and M.B.; formal analysis, C.P., M.R. and A.S.; investigation, C.P., M.B., R.M.; resources, M.R.; writing-original draft preparation, C.P.; writing-review and editing, C.P., M.R., A.S., M.B., R.M. and A.B.; visualisation, C.P.; supervision, A.B.; funding acquisition, M.R. All authors have read and agreed to the published version of the manuscript.

Funding: This research received no external funding.

Data Availability Statement: The data that support the findings of this study are available from the corresponding author upon reasonable request.

Conflicts of Interest: The authors declare no conflict of interests.

\section{References}

1. Lamorski, K.; Pachepsky, Y.; Sławiński, C.; Walczak, R.T. Using Support Vector Machines to Develop Pedotransfer Functions for Water Retention of Soils in Poland. Soil Sci. Soc. Am. J. 2008, 72, 1243-1247. [CrossRef]

2. Szypłowska, A.; Lewandowski, A.; Jones, S.B.; Sabouroux, P.; Szerement, J.; Kafarski, M.; Wilczek, A.; Skierucha, W. Impact of Soil Salinity, Texture and Measurement Frequency on the Relations between Soil Moisture and 20 MHz-3 GHz Dielectric Permittivity Spectrum for Soils of Medium Texture. J. Hydrol. 2019, 579, 124155. [CrossRef]

3. Zhao, B.; Li, L.; Zhao, Y.; Zhang, X. Thermal Conductivity of a Brown Earth Soil as Affected by Biochars Derived at Different Temperatures: Experiment and Prediction with the Campbell Model. Int. Agrophys. 2020, 34, 433-439. [CrossRef]

4. Farhadi-Machekposhti, M.; Valdes-Abellan, J.; Pla, C.; Benavente, D.; Pachepsky, Y. Impact of Marble Powder Amendment on Hydraulic Properties of a Sandy Soil. Int. Agrophys. 2020, 34, 223-232. [CrossRef]

5. Usowicz, B.; Lukowski, M.; Lipiec, J. The SMOS-Derived Soil Water EXtent and Equivalent Layer Thickness Facilitate Determination of Soil Water Resources. Sci. Rep. 2020, 10, 18330. [CrossRef]

6. Kiani-Harchegani, M.; Sadeghi, S.H.; Singh, V.P.; Asadi, H.; Abedi, M. Effect of Rainfall Intensity and Slope on Sediment Particle Size Distribution during Erosion Using Partial Eta Squared. CATENA 2019, 176, 65-72. [CrossRef]

7. Fernández-Raga, M.; Palencia, C.; Keesstra, S.; Jordán, A.; Fraile, R.; Angulo-Martínez, M.; Cerdà, A. Splash Erosion: A Review with Unanswered Questions. Earth Sci. Rev. 2017, 171, 463-477. [CrossRef]

8. Rochette, P.; Angers, D.A.; Chantigny, M.H.; Bertrand, N. Nitrous Oxide Emissions Respond Differently to No-Till in a Loam and a Heavy Clay Soil. Soil Sci. Soc. Am. J. 2008, 72, 1363-1369. [CrossRef]

9. Abdalla, K.; Chivenge, P.; Ciais, P.; Chaplot, V. No-Tillage Lessens Soil $\mathrm{CO}_{2}$ Emissions the Most under Arid and Sandy Soil Conditions: Results from a Meta-Analysis. Biogeosciences 2016, 13, 3619-3633. [CrossRef]

10. Walkiewicz, A.; Kalinichenko, K.; Kubaczyński, A.; Brzezińska, M.; Bieganowski, A. Usage of Biochar for Mitigation of $\mathrm{CO}_{2}$ Emission and Enhancement of CH4 Consumption in Forest and Orchard Haplic Luvisol (Siltic) Soils. Appl. Soil Ecol. 2020, 156, 103711. [CrossRef]

11. Balashov, E.; Kren, J.; Prochazkova, B. Influence of Plant Residue Management on Microbial Properties and Water-Stable Aggregates of Two Agricultural Soils. Int. Agrophys. 2010, 24, 9-13.

12. Navarro-García, F.; Casermeiro, M.Á.; Schimel, J.P. When Structure Means Conservation: Effect of Aggregate Structure in Controlling Microbial Responses to Rewetting Events. Soil Biol. Biochem. 2012, 44, 1-8. [CrossRef]

13. Oszust, K.; Frąc, M.; Lipiec, J. Soil Microbial Functionality in Response to Dairy Sewage Sludge and Mineral Fertilisers Application under Winter Rape. Int. J. Environ. Sci. Technol. 2015, 12, 3675-3684. [CrossRef]

14. Frąc, M.; Lipiec, J.; Usowicz, B.; Oszust, K.; Brzezińska, M. Structural and Functional Microbial Diversity of Sandy Soil under Cropland and Grassland. PeerJ 2020, 8, e9501. [CrossRef]

15. International Organisation for Standarisation ISO 11277. Soil Quality_Determination of Particle Size Distribution in Mineral Soil Material-Method by Sieving and Sedimentation; International Organization for Standarisation: Geneva, Switzerland, 2020.

16. Ryżak, M.; Bartmiński, P.; Bieganowski, A. Metody Wyznaczania Rozkładu Granulometrycznego Gleb Mineralnych; Intytut Agrofizyki im, Bohdana Dobrzańskiego PAN w Lublinie: Lublin, Poland, 2009; Volume 175. 
17. Polakowski, C.; Sochan, A.; Bieganowski, A.; Ryzak, M.; Földényi, R.; Tóth, J. Influence of the Sand Particle Shape on Particle Size Distribution Measured by Laser Diffraction Method. Int. Agrophys. 2014, 28, 195-200. [CrossRef]

18. Shang, Y.; Kaakinen, A.; Beets, C.J.; Prins, M.A. Aeolian Silt Transport Processes as Fingerprinted by Dynamic Image Analysis of the Grain Size and Shape Characteristics of Chinese Loess and Red Clay Deposits. Sediment. Geol. 2018, 375, 36-48. [CrossRef]

19. Kandler, K.; Schneiders, K.; Ebert, M.; Hartmann, M.; Weinbruch, S.; Prass, M.; Pöhlker, C. Composition and Mixing State of Atmospheric Aerosols Determined by Electron Microscopy: Method Development and Application to Aged Saharan Dust Deposition in the Caribbean Boundary Layer. Atmos. Chem. Phys. 2018, 18, 13429-13455. [CrossRef]

20. Kaszubkiewicz, J.; Papuga, K.; Kawałko, D.; Woźniczka, P. Particle Size Analysis by an Automated Dynamometer Method Integrated with an X-y Sample Changer. Measurement 2020, 157, 107680. [CrossRef]

21. Durner, W.; Iden, S.C.; von Unold, G. The Integral Suspension Pressure Method (ISP) for Precise Particle-Size Analysis by Gravitational Sedimentation: ISP METHOD FOR PARTICLE-SIZE ANALYSIS. Water Resour. Res. 2017, 53, 33-48. [CrossRef]

22. Faé, G.S.; Montes, F.; Bazilevskaya, E.; Añó, R.M.; Kemanian, A.R. Making Soil Particle Size Analysis by Laser Diffraction Compatible with Standard Soil Texture Determination Methods. Soil Sci. Soc. Am. J. 2019, 83, 1244-1252. [CrossRef]

23. Yang, Y.; Wang, L.; Wendroth, O.; Liu, B.; Cheng, C.; Huang, T.; Shi, Y. Is the Laser Diffraction Method Reliable for Soil Particle Size Distribution Analysis? Soil Sci. Soc. Am. J. 2019, 83, 276. [CrossRef]

24. Vodyanitskii, Y.N.; Savichev, A.T.; Morgun, E.G. Towards a New and General Method for Decoding the Soil Texture from Laser Diffraction Spectra. Environ. Earth Sci. 2020, 79, 266. [CrossRef]

25. Makó, A.; Szabó, B.; Rajkai, K.; Szabó, J.; Bakacsi, Z.; Labancz, V.; Hernádi, H.; Barna, G. Evaluation of Soil Texture Determination Using Soil Fraction Data Resulting from Laser Diffraction Method. Int. Agrophys. 2019, 33, 445-454. [CrossRef]

26. Joint Committee for Guides in Metrology JCGM 100:2008. GUM 1995 Ewaluacja Danych Pomiarowych Przewodnik Wyrażania Niepewności Pomiaru. In Évaluation Des Données de Mesure-Guide Pour L'Expression de L'Incertitude de Mesure; JCGM: Sèvres, France, 2010.

27. Goossens, D. Techniques to Measure Grain-Size Distributions of Loamy Sediments: A Comparative Study of Ten Instruments for Wet Analysis. Sedimentology 2008, 55, 65-96. [CrossRef]

28. Tavares, L.D.F.; Carvalho, A.M.X.D.; Machado, L.G. An Evaluation of the Use of Statistical Procedures in Soil Science. Rev. Bras. Ciência Solo 2016, 40. [CrossRef]

29. Bieganowski, A.; Ryżak, M.; Sochan, A.; Barna, G.; Hernádi, H.; Beczek, M.; Polakowski, C.; Makó, A. Laser Diffractometry in the Measurements of Soil and Sediment Particle Size Distribution. Adv. Agron. 2018, 15, 215-279.

30. FAO. World Reference Base for Soil Resources 2014: International Soil Classification System for Naming Soils and Creating Legends for Soil Maps; Update 2015; FAO: Rome, Italy, 2015; ISBN 978-92-5-108369-7.

31. Lamorski, K.; Sławiński, C.; Moreno, F.; Barna, G.; Skierucha, W.; Arrue, J.L. Modelling Soil Water Retention Using Support Vector Machines with Genetic Algorithm Optimisation. Sci. World J. 2014, 2014, 740521. [CrossRef]

32. Sperazza, M.; Moore, J.N.; Hendrix, M.S. High-Resolution Particle Size Analysis of Naturally Occurring Very Fine-Grained Sediment Through Laser Diffractometry. J. Sediment. Res. 2004, 74, 736-743. [CrossRef]

33. Fisher, P.; Aumann, C.; Chia, K.; Halloran, N.O.; Chandra, S. Adequacy of Laser Diffraction for Soil Particle Size Analysis. PLoS ONE 2017, 12, e0176510. [CrossRef]

34. Yang, X.; Zhang, Q.; Li, X.; Jia, X.; Wei, X.; Shao, M. Determination of Soil Texture by Laser Diffraction Method. Soil Sci. Soc. Am. J. 2015, 79, 1556. [CrossRef]

35. Igaz, D.; Aydin, E.; Šinkovičová, M.; Šimanský, V.; Tall, A.; Horák, J. Laser Diffraction as An Innovative Alternative to Standard Pipette Method for Determination of Soil Texture Classes in Central Europe. Water 2020, 12, 1232. [CrossRef]

36. Buurman, P.; Pape, T.; Reijneveld, J.A.; de Jong, F.; van Gelder, E. Laser-Diffraction and Pipette-Method Grain Sizing of Dutch Sediments: Correlations for Fine Fractions of Marine, Fluvial, and Loess Samples. Neth. J. Geosci. 2001, 80, 49-57. [CrossRef]

37. Konert, M.; Vandenberghe, J. Comparison of Laser Grain Size Analysis with Pipette and Sieve Analysis: A Solution for the Underestimation of the Clay Fraction. Sedimentology 1997, 44, 523-535. [CrossRef]

38. Roberson, S.; Weltje, G.J. Inter-Instrument Comparison of Particle-Size Analysers. Sedimentology 2014, 61, 1157-1174. [CrossRef]

39. Polakowski, C.; Ryżak, M.; Bieganowski, A.; Sochan, A.; Bartmiński, P.; Dębicki, R.; Stelmach, W. The Reasons for Incorrect Measurements of the Mass Fraction Ratios of Fine and Coarse Material by Laser Diffraction. Soil Sci. Soc. Am. J. 2015, 79, 30-36. [CrossRef]

40. Sochan, A.; Bieganowski, A.; Ryżak, M.; Dobrowolski, R.; Bartmiński, P. Comparison of Soil Texture Determined by Two Dispersion Units of Mastersizer 2000. Int. Agrophys. 2012, 26, 99-102. [CrossRef]

41. Deng, Y.; Cai, C.; Xia, D.; Ding, S.; Chen, J. Fractal Features of Soil Particle Size Distribution under Different Land-Use Patterns in the Alluvial Fans of Collapsing Gullies in the Hilly Granitic Region of Southern China. PLoS ONE 2017, 12, e0173555. [CrossRef]

42. Kondrlova, E.; Igaz, D.; Horak, J. Effect of Calculation Models on Particle Size Distribution Estimated by Laser Diffraction. In Proceedings of the 9th International Soil Science Congress on "The Soul of Soil and Civilization", Side, Antalya, Turkey, 14-16 October 2014; pp. 21-27.

43. Murray, M. Is Laser Particle Size Determination Possible for Carbonate Rick Lake Sediments? J. Paleolimnol. 2002, 27, 173-183. [CrossRef] 